\title{
Leptin and metabolic hormones in infants of diabetic mothers
}

\author{
P C Ng, C W K Lam, C H Lee, G W K Wong, T F Fok, E Wong, K C Ma, I H S Chan
}

\begin{abstract}
Aims-To investigate the effect of maternal diabetes on leptin in term newborns and to determine whether leptin correlates with insulin and its associated biochemical parameters in support of the hypothesis that a functional "adipoinsular axis" might exist at this stage of development.

Methods-A total of 116 term newborns were prospectively enrolled and categorised into three groups: 44 were infants of non-diabetic mothers (control group C); 41 were infants born to mothers with gestational diabetes on dietary treatment (group D); and 31 were infants born to mothers with gestational or pregestational diabetes on insulin treatment (group I).

Results-No significant difference in serum leptin was observed between the three groups; the results of the study population were therefore pooled and analysed. Serum leptin correlated significantly with serum insulin, insulin:glucose ratio, birth weight, body length, body mass index, placenta weight, and maternal HbA $_{1 \mathrm{c}}$. Female infants had significantly higher serum leptin than male infants. All parameters except placenta weight and body length remained significantly associated with serum leptin when multivariate stepwise regression analysis was applied. Subgroup analysis revealed a significant correlation between serum leptin and cortisol in group $\mathbf{D}$.
\end{abstract}

Conclusions-There was no significant difference in serum leptin between infants born to diabetic and non-diabetic mothers, though infants born to mothers requiring insulin treatment had the highest median serum leptin concentrations. The significant association between serum leptin and insulin or insulin:glucose ratio supports the hypothesis that a functional adipoinsular axis might exist in term newborns. Furthermore, the significant correlation between maternal $\mathbf{H b A}_{1 \mathrm{c}}$ and circulating leptin of the studied infants suggests that the clinical control of maternal diabetes could affect the regulation of serum leptin in these infants.

(Arch Dis Child Fetal Neonatal Ed 2000;83:F193-F197)

Keywords: leptin; insulin; diabetes; adipoinsular axis

The recently discovered hormone leptin, a 16 $\mathrm{kDa}$ adipocyte derived protein encoded by the $o b$ gene, has provided important insight into the physiology of neuroendocrine regulation of body fat content, feeding behaviour, and energy homoeostasis in rodents and humans. ${ }^{1-4}$ Leptin functions as an afferent satiety signal from the peripheral fat mass to the hypothalamus, and controls the basal metabolic rate and energy expenditure of the body. ${ }^{5}$ Accumulating evidence suggests that leptin exerts its metabolic effects by interacting with other hormonal systems. Leptin has been reported to suppress the secretion of insulin from the pancreatic $\beta$ cells, ${ }^{7}$ and modulate the action of insulin on hepatocytes. ${ }^{8}$ A mutation in the $o b$ gene in the rodent prevents normal leptin production and causes both obesity and diabetes, ${ }^{1}$ whereas treatment of the $o b / o b$ mice with leptin results in decrease of body weight and normalisation of blood glucose. ${ }^{9}$ Leptin also modifies the functioning of both the hypothalamic-pituitary-adrenal (HPA) and the sympathetic-adrenomedullary axis in controlling fat cell proliferation and body metabolic activity. ${ }^{10-12}$ In both rodents and humans, there is a strict reciprocal diurnal association between serum leptin and cortisol concentrations. $^{1314}$ In addition, ACTH induced adrenal cortisol, aldosterone, and dehydroepiandrosterone secretion has been shown to be inhibited by leptin in a concentration dependent manner. ${ }^{15}$ Circulating leptin also influences haematopoietic stem cell function ${ }^{16}{ }^{17}$ and oestradiol activity. ${ }^{18}$

As pregnancy is associated with profound changes in adipose tissue/lipid and hormonal metabolism such as increase in insulin, corticotrophin releasing hormone $(\mathrm{CRH})$, cortisol, oestrogens, and progesterone concentrations, it is important to understand the physiological role of leptin in newborns with regard to normal and disease pregnancy states. To date, most newborn studies have concentrated on the relation of leptin on fetal growth and anthropometric measurements at birth. ${ }^{19-24}$ Significant associations between umbilical cord serum leptin and birth weight, body mass index (BMI), and arm fat have been well documented. ${ }^{20-24}$ However, the effects of pregnancy induced hyperglycaemia (gestational diabetes, one of the most frequent complications of pregnancy) and maternal insulin dependent diabetes on leptin and other metabolic hormones in newborns, have not been systematically evaluated. This study was, therefore, undertaken to investigate the effect of maternal diabetes on serum leptin in term newborns. The inter-relations between leptin and other metabolic hormones including insulin, insulin:glucose ratio (an index of glucose metabolism), corticotropin (ACTH), cortisol, thyroid stimulating hormone (TSH), and free 
Table 1 Clinical characteristics of the study populations

\begin{tabular}{|c|c|c|c|}
\hline & Group $C(n=44)$ & Group $D(n=41)$ & Group $I(n=31)$ \\
\hline Birth weight $(\mathrm{g})$ & $3458(684)$ & $3250(538)$ & $3399(572)$ \\
\hline Length $(\mathrm{cm})$ & $49.6(2.9)$ & $48.7(2.0)$ & $48.7(2.5)$ \\
\hline $\mathrm{BMI}\left(\mathrm{kg} / \mathrm{m}^{2}\right)$ & $13.9(1.7)$ & $13.6(1.6)$ & $14.3(1.6)$ \\
\hline Placental weight $(\mathrm{g})$ & $570(94)$ & $556(99)$ & $563(126)$ \\
\hline Male:female (n) & $23: 21$ & $28: 13$ & $15: 16$ \\
\hline $\begin{array}{l}\text { Mode of delivery (n) } \\
\text { (normal: caesarean } \\
\text { section: forcep or } \\
\text { ventouse) }\end{array}$ & $22: 13: 9$ & $18: 14: 9$ & $16: 12: 3$ \\
\hline Maternal smoker (n) & 1 & 3 & 0 \\
\hline \multicolumn{4}{|l|}{ Apgar scores } \\
\hline at $1 \mathrm{~min}$ & $9(8-9)$ & $9(8.75-9)$ & $9(8-10)$ \\
\hline at $5 \mathrm{~min}$ & $10(9-10)$ & $10(10-10)$ & $10(9-10)$ \\
\hline \multicolumn{4}{|l|}{ Arterial cord blood } \\
\hline $\mathrm{pH}$ & $7.27(7.22-7.30)$ & $7.27(7.18-7.31)$ & $7.25(7.19-7.27)$ \\
\hline Base excess & $-6.6(-3.8$ to -7.9$)$ & $-6.7(-5.4$ to -8.5$)$ & $-6.3(-4.6$ to -8.2$)$ \\
\hline Maternal $\mathrm{HbA}_{1 \mathrm{c}}{ }^{\star}$ & - & $4.84(0.44)$ & $6.05(1.12)$ \\
\hline
\end{tabular}

Results are expressed as mean (SD) or median (interquartile range).

${ }^{\star} \mathrm{p}<0.05$. patient. Blood was collected: (1) in a prechilled plain tube for serum leptin, insulin, cortisol, and FT4; (2) in a prechilled EDTA bottle for plasma ACTH; and (3) in a fluoride tube for plasma glucose measurement. These blood samples were immediately immersed in ice and transported to the laboratory for processing. All samples were centrifuged at $3500 \mathrm{rpm}$ for 15 minutes at $4^{\circ} \mathrm{C}$, and the resulting plasma/ serum stored at $-70^{\circ} \mathrm{C}$ until analysis. Umbilical cord blood TSH was routinely obtained immediately after birth for neonatal screening of congenital hypothyoidism.

\section{HORMONE ASSAYS}

Serum leptin and FT4 were measured by enzyme linked immunosorbent assay (ELISA, Diagnostic Systems Laboratories Inc., Webster, Texas, USA) and chemiluminescence immunoassay (ACS:180 analyser, CIBACorning Diagnostic Corp., Medfield, Massachusetts, USA), respectively. Serum insulin was measured by microparticle immunoassay (IMx analyser, Abbott Laboratories, Abbott Park, Illinois, USA) and plasma glucose was determined by the glucose oxidase method (Hitachi 911 analyser, Boehringer Mannheim GmbH, Mannheim, Germany). The IMx insulin assay does not show any cross reactivity with proinsulin $(<0.005 \%)$. Plasma ACTH and serum cortisol were measured by double antibody radioimmunoassay (RIA, Nichols Institute Diagnostics, San Juan Capistrano, California, USA) and solid phase RIA (Diagnostic Products Corp., Los Angeles, California, USA), respectively as previously described. ${ }^{27}$ The sensitivity and interassay coefficients of variation of leptin, ACTH, cortisol, FT4, insulin, and glucose were: $0.05 \mathrm{ng} / \mathrm{ml}$, $3.5 \%$ at $2.2 \mathrm{ng} / \mathrm{ml} ; 0.22 \mathrm{pmol} / 1,5.2 \%$ at 7.8 $\mathrm{pmol} / 1 ; 5.5 \mathrm{nmol} / 1,4.2 \%$ at $407 \mathrm{nmol} / 1 ; 1.3$ $\mathrm{pmol} / 1,2.9 \%$ at $13 \mathrm{pmol} / 1 ; 7.2 \mathrm{pmol} / 1,5.6 \%$ at $38 \mathrm{pmol} / 1$; and $0.2 \mathrm{mmol} / 1,1.7 \%$ at $5.0 \mathrm{mmol} / 1$, respectively. The plasma/serum volume required for hormonal analysis was: $50 \mu \mathrm{l}, 200 \mu \mathrm{l}$, $200 \mu \mathrm{l}, 200 \mu \mathrm{l}, 180 \mu \mathrm{l}$, and $20 \mu \mathrm{l}$, respectively. The umbilical cord blood TSH was routinely measured by the Hong Kong Government Laboratory as part of the territory wide neonatal screening for congenital hypothyoidism. Leptin and metabolic hormones were analysed by the laboratory in a blinded fashion.

\section{DATA COLLECTION}

Anthropometric measurements including body weight and length were recorded at birth and BMI was calculated as body weight $(\mathrm{kg}) /$ square of length $\left(\mathrm{m}^{2}\right) \cdot{ }^{28}$ Body length was measured by the Harpenden infantometer. Table 1 presents demographic and clinical data of the study population.

ETHICAL APPROVAL

Ethical approval of the study was obtained from the Clinical Research Ethical Committee of the Chinese University of Hong Kong. Informed parental consent was obtained for each patient before commencement of the test. 
Table 2 Blood hormone and plasma glucose concentrations on the first day of life

\begin{tabular}{llll}
\hline & Group $C(n=43)$ & Group $D(n=40)$ & Group $I(n=31)$ \\
\hline Age of first blood sample $(\mathrm{h})$ & $26.8(6.4)$ & $26.8(7.0)$ & $27.3(8.9)$ \\
Leptin $(\mathrm{ng} / \mathrm{ml})$ & $1.58(0.47-6.33)$ & $1.17(0.50-2.05)$ & $2.13(0.58-9.04)$ \\
ACTH $(\mathrm{pmol} / \mathrm{l})$ & $8.3(4.9-18.6)$ & $8.1(4.8-15.2)$ & $10.1(6.1-16.5)$ \\
Cortisol $(\mathrm{nmol} / \mathrm{l})$ & $308(206-406)$ & $264(145-387)$ & $340(217-564)$ \\
Insulin $(\mathrm{pmol} / \mathrm{ml}) \dagger$ & $24.4(7.2-53.1)$ & $32.7(20.3-54.9)$ & $56.0(36.6-86.8)$ \\
Glucose $(\mathrm{mmol} / \mathrm{l})$ & $4.1(3.7-4.7)$ & $4.4(3.7-5.0)$ & $4.2(3.6-5.3)$ \\
Insulin:glucose ratio & $6.4(2.2-10.8)$ & $8.8(4.4-13.4)$ & $13.0(8.2-23.0)$ \\
FT4 (pmol/l) & $28.2(22.6-33.3)$ & $29.4(24.8-34.1)$ & $29.0(25.2-33.2)$ \\
Cord TSH (mIU/l) & $4.9(3.9-7.3)$ & $5.5(4.2-7.2)$ & $5.3(3.6-9.1)$ \\
\hline
\end{tabular}

Results are expressed as mean (SD) or median (interquartile range).

${ }^{\star} \mathrm{p}<0.002 ; \mathrm{tp}<0.001$.

Table 3 Significant correlations between different metabolic hormones and clinical parameters

\begin{tabular}{lll}
\hline & Correlation $(r)$ & $p$ value \\
\hline Leptin & & \\
Insulin & 0.26 & $<0.01$ \\
Insulin:glucose ratio $_{\text {Maternal HbA }}$ (groups D and I) & 0.28 & $<0.005$ \\
$\quad$ Placenta weight & 0.39 & $<0.001$ \\
Birth weight & 0.30 & $<0.001$ \\
Body length & 0.54 & $<0.001$ \\
BMI & 0.34 & $<0.001$ \\
Insulin & 0.53 & $<0.001$ \\
Leptin & 0.26 & $<0.01$ \\
Glucose & 0.22 & $<0.05$ \\
Placental weight & 0.25 & $<0.01$ \\
Exogenous insulin dose (group I) & 0.58 & $<0.001$ \\
Maternal HbA & \\
Leptin & & $<0.001$ \\
Insulin:glucose ratio & 0.39 & $<0.005$ \\
Leptin & & $<0.05$ \\
Placental weight & 0.28 & $<0.001$ \\
Exogenous insulin dose (group I) & 0.24 & $<0.001$ \\
ACTH & 0.48 & \\
$\quad$ Cortisol & 0.44 & \\
\hline
\end{tabular}

STATISTICAL ANALYSIS

The clinical and anthropometric parameters of the study populations were expressed as mean (SD). Apgar scores, umbilical arterial cord blood parameters, serum leptin, and other metabolic hormone concentrations followed a non-Gaussian distribution and were expressed as median (interquartile range). One way ANOVA and Kruskal-Wallis tests with post hoc pairwise multiple comparisons were used to compare the parametric and non-parametric parameters, respectively between the three groups. Spearman's correlation coefficient was used to evaluate the inter-relations between different metabolic hormones, and the relations of the metabolic hormones to birth weight, BMI, and other demographic or clinical parameters. The Mann-Whitney U test was also used to assess possible differences between various metabolic hormones and sex. Statistically significant parameters associated with leptin were further subjected to multivariate stepwise regression analysis. Logarithmic transformation of metabolic hormone concentrations was necessary as these concentrations were not normally distributed. Statistical tests were performed by SPSS for Windows ( $\mathrm{Re}$ lease 9.0, SPSS Inc., Chicago, Illinois) and BMDP/Dynamic (Release 7, BMDP, Statistical Software Inc., Los Angeles, California). The level of significance was set at $5 \%$ in all comparisons.

\section{Results}

Table 1 summarises the clinical characteristics of the study population. Maternal $\mathrm{HbA}_{1 \mathrm{c}}$ was significantly higher in group I than in group D $(\mathrm{p}<0.05)$, but none of the other parameters listed in the table differed significantly between the three groups.

Table 2 summarises the results of the metabolic hormones and plasma glucose. No significant difference in serum leptin was observed between the three groups. Serum insulin was significantly higher in group I than in group $\mathrm{C}$; and insulin:glucose ratio was significantly higher in group I than in groups $\mathrm{C}$ and D. In addition, there were significant correlations between serum leptin and cortisol in group $\mathrm{D}(\mathrm{p}<0.05, r=0.36)$.

The results of the study population were then pooled and analysed. Table 3 summarises significant associations between different metabolic hormones and clinical parameters. Serum leptin was found to correlate significantly with serum insulin, insulin:glucose ratio, birth weight, body length, BMI, placenta weight, and maternal $\mathrm{HbA}_{1 \mathrm{c}}$ (groups $\mathrm{D}$ and I). Female infants had significantly higher serum leptin concentration than male infants $(p<0.002)$. When these parameters (maternal $\mathrm{HbA}_{1 \mathrm{c}}$ excluded) were subjected to multivariate stepwise regression analysis, all except placenta weight and body length remained significantly correlated with serum leptin.

\section{Discussion}

This study investigated the inter-relations between serum leptin and other major metabolic hormones in newborns of diabetic and non-diabetic mothers. Although it has been shown in adults that leptin is closely associated with insulin, ${ }^{29-34}$ a similar relation has not been consistently shown in newborn infants. Most newborn studies have concentrated on the association between serum leptin and anthropometric parameters at birth. ${ }^{19-23}$ Very few studies have investigated the relation between serum leptin and insulin, ${ }^{22} 2435$ and to our knowledge, only one has shown a significant connection between serum leptin and insulin in newborn infants. ${ }^{24}$ Moreover, the influence of maternal diabetes on leptin, and the interaction of leptin with other major metabolic pathways such as the pituitary-thyroid and HPA axis in newborns are not yet fully elucidated. Hence, we sought to determine whether an "adipoinsular" or other leptin related hormonal axis exists in term newborns and whether such relations are affected by maternal diabetes.

Our results did not show a significant difference in serum leptin between term infants born to diabetic and non-diabetic mothers. However, it is worth noting that infants born to mothers requiring insulin treatment (group I) had the highest median serum leptin concentrations (table 2). The wide variation in serum leptin and the relatively small sample size in individual groups might have contributed to these insignificant differences. More importantly, significant associations between serum leptin and insulin, insulin:glucose ratio and maternal $\mathrm{HbA}_{1 \mathrm{c}}$ support the hypothesis that a functional "adipoinsular axis" might exist in term newborns. It is most likely that excess 
maternal glucose crosses the placenta and stimulates an increase in insulin production of the fetus. Fetal insulin up regulates the $o b$ gene expression and induces leptin production by the adipocytes. Leptin functions as a counter regulatory hormone and inhibits insulin production by activating the ATP sensitive potassium channels in the pancreatic $\beta$ cells. ${ }^{31}$ This negative feedback mechanism has been extensively studied in rodents both in vivo and in vitro, ${ }^{37}$ and has also been observed in human adults after prolonged administration of insulin. ${ }^{34}$ Three studies have investigated the effect of maternal diabetes on newborn serum leptin and showed that infants of diabetic mothers, especially those on insulin treatment, have higher umbilical cord serum leptin concentration. $^{363940}$ None of these studies, however, showed a significant correlation between serum leptin and insulin or insulin:glucose ratio. ${ }^{39}{ }^{40}$ Only the subgroup analysis by Maffei et al revealed a significant association between serum leptin and insulin, $\mathrm{C}$ peptide, and maternal $\mathrm{HbA}_{1 \mathrm{c}}$ in eight neonates born to insulin dependent diabetic mothers. ${ }^{36}$ In addition, a significant association between maternal $\mathrm{HbA}_{1 \mathrm{c}}$ and circulating leptin of our studied infants suggests that the regulation of serum leptin concentrations in term newborns may be influenced by the clinical control of maternal diabetes.

Our subgroup analysis also showed a significant association between serum leptin and cortisol in group D infants. As pharmacological doses of dexamethasone have been shown to induce leptin production ${ }^{29} 40-42$ and insulin could block the dexamethasone stimulated increase in leptin release, ${ }^{43}$ our observation suggests the possibility that serum leptin in term newborns may be influenced by circulating cortisol. However, it would be unlikely that cortisol could act directly by stimulating $o b$ gene transcription, ${ }^{29}$ but cortisol might interact indirectly with other hormonal systems such as the insulin/glucose pathway in affecting serum leptin.

Our study also confirms the consistent relation between serum leptin and birth weight or BMI. ${ }^{19-21} 2439{ }^{40}$ Again, a sex difference in serum leptin concentration was observed. Female infants had significantly higher serum leptin concentrations than male infants suggesting that sexual dimorphism exists in utero. ${ }^{1924}$

In summary, our results did not show a significant difference in serum leptin between infants born to diabetic and non-diabetic mothers, though infants born to mothers requiring insulin treatment had the highest median serum leptin concentrations. There were significant associations between serum leptin and insulin or insulin:glucose ratio, supporting the hypothesis that a functional adipoinsular axis might be present in the term newborns. In addition, a significant correlation between maternal $\mathrm{HbA}_{1 \mathrm{c}}$ and serum leptin in the studied infants suggests that the clinical control of maternal diabetes could influence the concentration of circulating leptin in these infants. Accumulating evidence indicates that maternal diabetes could affect fetal leptin

\section{Key message}

An active "adipoinsular axis" is likely to exist in term newborns. The clinical control of maternal diabetes may affect the regulation of serum leptin and possibly may also influence the growth of the fetus in utero

metabolism. ${ }^{39} 40$ Although a definite relation could not be established between leptin and cortisol at this stage, the present data suggest the possibility that serum leptin in newborns may be influenced by circulating cortisol. Despite the associations between leptin and various metabolic hormones, further experimental and clinical investigations are required to determine their causal relations and their physiological role in controlling fetal and neonatal growth at this crucial stage of human development.

1 Zhang Y, Proenca R, Maffei M, Barone M, Leopold L, Friedman JM. Positional cloning of the mouse obese gene and its human homologue. Nature 1994;372:425-32.

2 Campfield LA, Smith FJ, Guisez Y, Devos R, Burn P. Recombinant mouse $O B$ protein: evidence for a peripherial signal linking adiposity and central neural network. Science 1995;269:546-9.

3 Considine RV, Sinha MK, Heiman ML, et al. The protein product of $a b$ gene is elevated in human obesity: effect of weight loss, fasting and feeding. $N$ Engl $f \mathrm{Med}$ weight loss, fastir

4 Salbe AD, Nicolson M, Ravussin E. Total energy expenditure and the level of physical activity correlate with plasma leptin concentrations in five-year-old children. 7 Clin Invest 1997;99:592-5.

5 Seeley RJ, Schwartz MW. Neuroendocrine regulation of food intake. Acta Paediatr Suppl 1999;428:58-61.

6 Auwerx J, Staels B. Leptin. Lancet 1998;351:737-42.

7 Kieffer TJ, Heller RS, Habener JF. Leptin receptors expressed on pancreatic $\beta$ cells. Biochem Biophys Res Commun 1996;224:522-7.

8 Cohen B, Novick D, Rubinstein M. Modulation of insulin activities by leptin. Science 1996;274:1185-8.

9 Pelleymounter MA, Cullen MJ, Baker MB, et al. Effects of the obese gene product on body weight regulation in $\mathrm{ob} / \mathrm{ob}$ mice. Science 1995;269:540-3.

10 Dallman MF, Akona SF, Strack AM, Hanson ES, Sebastian RJ. The neural network that regulates energy balance is responsive to glucocorticoids and insulin and also regulates HPA axis responsivity at a site proximal to CRF neurons. Ann N Y Acad Sci 1995;771:730-42.

11 Tataranni PA, Larson DE, Snitker S, Young JB, Flatt JP, Ravussin E. Effects of glucocorticoids on energy metabolism and food intake in humans. Am $\mathcal{F}$ Physiol 1996;271:E317-25

12 Reaven GM, Lithell H, Landsbery L. Hypertension and associated metabolic abnormalities - the role of insulin resistance and the sympathoadrenal system. $N$ Engl F Med 1996;334:374-81.

13 Licinio J, Mantzoros C, Negrao AB, et al. Human leptin levels are pulsatile and inversely related to pituitary-adrenal function. Nat Med 1997;3:575-9.

14 Bornstein SR. Is leptin a stress related peptide? Nat Med 1997;3:937.

15 Glasow A, Haidan U, Hilbers M, et al. Expression of $o b$ receptor in normal human adrenals: differential regulation of adrenocortical and adrenomedullary function by leptin. of Clin Endocrinol Metab 1998;83:4459-66.

16 Päth G, Bornstein SR, Ehrhart-Bornstein M, Scherbaum WA. Interleukin- 6 and the interleukin 6 receptor in the human adrenal gland: expression and effects on steroidohuman adrenal gland: expression and effects on ster

17 Wang Y, Kuropatwinski KK, White DW, et al. Leptin receptor action in hepatic cells. $\mathcal{F}$ Biol Chem 1997;272:1621623.

18 Zachow RJ, Magoffin DA. Direct intraovarian effects of leptin: impairment of the synergistic action of insulin-like growth factor- $i$ on follicle-stimulating hormonedependent estradiol-17 $\beta$ production by rat ovarian granulosa cell. Endocrinology 1997;138:847-50.

19 Jaquet D, Leger J, Levy-Marchal C, Oury JF, Czernichow P. Ontogeny of leptin in human fetuses and newborns: effect of intrauterine growth retardation on serum leptin of intrauterine growth retardation on serum leptin

20 Marchini G, Fried G, Östlund E, Hagenäs I Pl:1243-6. in infants: relations to birth weight and weight loss. Pediatrics 1998;101:429-32.

21 Hassink SG, de Lancey E, Sheslow DV, et al. Placental leptin: an important new growth factor in intrauterine and www.pediatrics.org/cgi/content/full/100/1/el. 
22 Harigaya A, Nagashima K, Nako Y, Morikawa A. Relationship between concentration of serum leptin and fetal
growth. $\mathcal{F}$ Clin Endocrinol Metab 1997;82:3281-4.

23 Mantzoros CS, Varvarigou A, Kaklamani VG, Beratis NG, Flier J. Effect of birth weight and maternal smoking on cord blood leptin concentrations of full-term and preterm newborns. F Clin Endocrinol Metab 1997;82:2856-61.

24 Ong KKL, Ahmed ML, Sherriff A, et al. Cord blood leptin is associated with size at birth and predicts infancy weight gain in humans. F Clin Endocrinol Metab 1999;84:1145-8.

25 Martin FIA. The diagnosis of gestational diabetes. Med $\mathcal{f}$ Aust 1991;155:112

26 Ballard JL, Khoury JC, Wedig K, Wang L, Eiler-Walsman BL, Lipp R. New Ballard Score, expanded to include extremely premature infants. F Pediatr 1991:119:417-23.

$27 \mathrm{Ng}$ PC, Wong GWK, Lam CWK, et al. The pituitaryadrenal responses to exogenous human corticotropinreleasing hormone in preterm, very low birth weight infants. F Clin Endocrinol Metab 1997;82:797-9.

28 Cole TJ, Freeman JV, Preece MA. Body mass index reference curves for the UK, 1990. Arch Dis Child reference curves

29 Kolaczynski JW, Goldstein BJ, Considine RV. Dexamethasone, $O B$ gene, and leptin in humans; effect of exogenous hyperinsulinemia. F Clin Endocrinol Metab 1997;82:3895-7.

30 Seufert J, Kieffer TJ, Leech CA, et al. Leptin suppression of insulin secretion and gene expression in human pancreatic islets: implications for the development of adipogenic diabetes mellitus. F Clin Endocrinol Metab 1999;84:670-6.

31 Kieffer TJ, Heller S, Leech CA, Holz GG, Habener JF. Leptin suppression of insulin secretion by the activation of ATP-sensitive $\mathrm{K}^{+}$channels in pancreatic $\beta$-cells. Diabetes 1997;46:1087-93.

32 Emilsson V, Liu YL, Cawthorne MA, Morton NM, Davenport $M$. Expression of the functional leptin receptor mRNA in pancreatic islets and direct inhibitory action of leptin on insulin secretion. Diabetes 1997;46:313-6.

33 Segal KR, Landt M, Klein S. Relationship between insulin sensitivity and plasma leptin concentration in lean and obese men. Diabetes 1996;45:988-91.
34 Kolaczynski JW, Nyce MR, Considine RV, et al. Acute and chronic effect of insulin on leptin production in humans. Diabetes 1996;45:699-701.

35 Schubring C, Siebler T, Kratzsch J, et al. Leptin serum concentrations in healthy neonates within the first week of life: relation to insulin and growth hormone levels, skinfold thickness, body mass index and weight. Clin Endocrinol 1999;51:199-204

36 Maffei M, Volpe L, Di Cianni G, et al. Plasma leptin levels in newborns from normal and diabetic mothers. Horm Metab Res 1998;30:575-80.

37 Saladin R, De Vos P, Guerre-Millo M. Transient increase in obese gene expression after food intake or insulin administration. Nature 1995;377:527-9.

38 Cusin I, Sainsbury A, Doyle P, Rohner-Jeanrenaud F, Jeanrenaud $\mathrm{B}$. The $o b$ gene and insulin: a relationship leading to clues to the understanding of obesity. Diabetes 1995; $44: 1467-70$.

39 Gross GA, Solenberger T, Philpott T, Holcomb WL, Landt M. Plasma leptin concentrations in newborns of diabetic and non-diabetic mothers. Am f Perinatol 1998;15:243-7.

40 Shekhawat PS, Garland JS, Shivpuri C, et al. Neonatal cord blood leptin: its relationship to birth weight, body mass index, maternal diabetes, and steroid. Pediatr Res 1998;43:338-43.

41 Miell SP, Englaro P, Blum WT. Dexamethasone induces an acute and sustained rise in circulating leptin levels in normal human subjects. Horm Metab Res 1996;28:704-7.

42 Larsson H, Ahren B. Short-term dexamethasone treatment increases plasma leptin independently of changes in insulin sensitivity in healthy women. $\mathcal{F}$ Clin Endocrinol Metab 1996;81:4428-32.

43 Considin RV, Nyce MR, Kolaczynski JW, et al. Dexamethasone stimulates leptin release from human adipocytes: unexpected inhibition by insulin. $\mathcal{f}$ Cell Biochem 1997;64:254-8.

\section{Rapid responses}

Letters on the following papers have been published recently as rapid responses on the ADC website. To read these letters visit www.archdischild.com and click on "read rapid responses":

The impact of diagnostic delay on the course of acute appendicitis. V C Cappendijk, F W J Hazebroek. Arch Dis Child 2000;83:64-6.

Neonatal group B streptococcal disease associated with infected breast milk. W J Olver, D W Bond, T C Boswell, et al. Arch Dis Child Fetal Neonatal Ed 2000;83:48-9.

Malignant infantile osteopetrosis presenting with neonatal hypocalcaemia. M Srinivasan, M Abinun, A J Cant, K Tan, et al. Arch Dis Child Fetal Neonatal Ed 2000;83:21-3.

Lung deposition of aerosol-a comparison of different spacers. H J Zar, E G Weinberg, H J Binns, et al. Arch Dis Child 2000;82:495-8.

Neonatal group B streptococcal infection in South Bedfordshire, 1993-1998. K Beardsall, M H Thompson, R J Mulla, A Nicoll, et al. Arch Dis Child Fetal Neonatal Ed 2000;82:F205-7.

If you would like to post an electronic response to these or any other articles published in the journal, please go to the website, access the article in which you are interested, and click on "eLetters: Submit a response to this article" in the box in the top right hand corner. 